\title{
Dengue haemorrhagic fever in a neonate: red alert for neonatal care-givers
}

\author{
M Weerasekera ${ }^{1}, *$ V P Sinhabahu ${ }^{2}$, K M S S Ratnasiri ${ }^{2}$ \\ Sri Lanka Journal of Child Health, 2015; 44(2): 112-113
}

(Key words: Dengue haemorrhagic fever, neonate)

\section{Introduction}

Incidence of dengue infection in Sri Lanka in 2013 was $32,063^{1}$. Reported cases of dengue fever (DF) or dengue haemorrhagic fever (DHF) are rare in neonates. We report a case of DHF in a neonate which is the second documented case presented to this unit within two years.

\section{Case Report}

A four day old baby boy was admitted to the special care baby unit as mother was hospitalized for management of fever. Subsequently, the mother was managed as DHF complicated by myocarditis.
Baby was born vaginally at 38 weeks of period of amenorrhoea with a birth weight of $2680 \mathrm{~g}$. Antenatal and intrapartum periods were uncomplicated.

One day after admission, he developed fever. Hepatomegaly or rashes were not noted on examination. Intravenous (IV) crystalline penicillin and amikacin were started after taking blood for culture. As mother was treated as DHF, NS 1 antigen was done on day 2 of illness and it was positive. Dengue IgM and IgG were negative on day one of fever. Results of serial full blood counts are shown in Table 1.

Table 1: Results of serial full blood counts

\begin{tabular}{|l|c|c|c|c|c|}
\hline & $\mathbf{2}^{\text {nd }} \mathbf{d a y}$ & $\mathbf{3}^{\text {rd }} \mathbf{d a y}$ & $\mathbf{4}^{\text {th }} \mathbf{d a y}$ & $\mathbf{5}^{\text {th }}$ day & $\mathbf{6}^{\text {th }}$ day \\
\hline White cells $\left(\mathrm{mm}^{-3}\right)$ & 7,850 & 10,360 & 11,130 & 21,000 & 20,940 \\
\hline Neutrophils (\%) & 52 & 37 & 23 & 34 & 46 \\
\hline Lymphocytes (\%) & 19 & 58 & 65 & 50 & 49 \\
\hline Platelets $\left(10^{3} / \mathrm{mm}^{3}\right)$ & 115 & 26 & 7 & 23 & 30 \\
\hline Haemoglobin $(\mathrm{g} / \mathrm{dl})$ & 16.8 & 17.5 & 16 & 15.5 & 15.2 \\
\hline Haematocrit $(\%)$ & 48 & 49.7 & 45 & 43 & 43 \\
\hline
\end{tabular}

Ultrasound scans of the abdomen and chest, done on the fourth day of illness, showed fluid around the gall bladder and ascites. Pleural effusion or splenomegaly was not detected. With the evidence of leakage, baby was managed as DHF.

Critical phase of DHF occurred on $3^{\text {rd }}$ and $4^{\text {th }}$ days of illness and he was managed accordingly. Baby was lethargic during this period. He did not develop any bleeding manifestations. Alanine transaminase (ALT) and aspartate transaminase (AST) were $18 \mathrm{U} / \mathrm{L}$ and 54 $\mathrm{U} / \mathrm{L}$ on Day 4 of illness. He was given a platelet transfusion on $4^{\text {th }}$ day of illness. Intravenous vitamin $\mathrm{K} 1 \mathrm{mg}$ was also given. During the recovery phase on

${ }^{1}$ Consultant Neonatologist, ${ }^{2}$ Registrar in Paediatrics, Sri Jayewardenepura General Hospital, Nugegoda

*Correspondence: sinbad.lk@gmail.com

(Received on 26 March 2014: Accepted after revision on 30 May 2014) $6^{\text {th }}$ day of illness, he developed a fever spike. C reactive protein was $42 \mathrm{mg} / \mathrm{L}$. Throughout the clinical course of the illness, he was haemodynamically stable. He was treated as sepsis with IV antibiotics. He was discharged on $10^{\text {th }}$ day of illness Dengue Ig $\mathrm{M}$ done on $9^{\text {th }}$ day of illness was positive and Dengue Ig $\mathrm{G}$ was negative.

\section{Discussion}

DHF/DSS is very rare in the neonate and reported cases are $\mathrm{few}^{2}$. Mother was previously infected by dengue virus and hence has already developed antibody against that virus; the neonate or the infant may have placentally transmitted antibodies and may develop DHF after the first infection by dengue virus of antigenically different type ${ }^{2}$.

Baby did not have leucopenia at any stage of the course of illness. DHF in infancy may not have leukopenia ${ }^{3}$. Positive NS 1 antigen on day 2 of fever 
helped in diagnosis of current dengue infection in our patient. Diagnostic sensitivity of NS1 detection in the febrile phase can exceed $90 \%{ }^{4}$. Baby might have got the infection by vertical transmission or acquired by a mosquito bite. Incubation period of dengue virus (DV) infection is $3-7$ days $^{5}$. DENV -1 and DENV 3 are known to cause DHF in primary infection ${ }^{5}$. Due to lack of facilities for virus isolation, serotype of the virus could not be determined.

Sudden marked increase in white blood cell count (WBC) occurred on the $5^{\text {th }}$ day of illness. Bleeding and infections are known causes of marked $\mathrm{WBC}$ rise in DHF. With elevated CRP, WBC rise was thought to be due to sepsis. Platelet transfusions neither prevent development of severe bleeding nor shorten the time to cessation of bleeding in adults ${ }^{6}$. Transfusion of platelets was given on $4^{\text {th }}$ day when platelet count was $7,000 / \mathrm{mm}^{3}$ as neonates have a high risk of bleeding with platelet counts with platelet counts $<50,000$ irrespective of the underlying aetiology ${ }^{7}$.

Clinical manifestations of DHF/DSS are more significantly associated with death in infants compared with older children. Vertical transmission of DV and anti-DV IgG has been well reported and is responsible for the pathogenesis of dengue and its manifestations in infants ${ }^{8}$. Neonatal DHF is rare. Only a few cases of DHF are reported worldwide. Complex pathogenesis of DHF/DSS during primary dengue in infants/neonates, scarcity of clinical experience and unavailability of management guidelines for dengue infection in neonates makes the management of neonatal DHF a daring clinical encounter.

It is timely that all grades of medical staff handling paediatric patients be alert about dengue in neonates/young infants presenting with febrile illness and unexplained ill health.

\section{References}

1. Epidemiology unit, Ministry of Health web site http://www.epid.gov.lk viewed on 18.03.2014.

2. Choudhry P, Gupta RK, Kishan J. Dengue shock syndrome in newborn- a case series. Indian Pediatrics 2004; 41:397-9.

PMid: 15123872

3. Guidelines on management of dengue fever and dengue haemorrhagic fever in children and adolescents: revised and expanded edition, December 2012. Ministry of Health, Sri Lanka.

4. Simmons CP, Farrar JJ, Van Vinh Chau N, Wills B. Dengue. New England Journal of Medicine 2012; 366:1423-32.

http://dx.doi.org/10.1056/NEJMra1 110265

PMid: 22494122

5. Sellahewa K.H. Pathogenesis of dengue haemorrhagic fever and its impact on case management. ISRN Infectious Diseases. Volume 2013 (2013), viewed on 2014.02.27 in:

http://www.hindawi.com/journals/isrn.infectious. diseases/2013/571646/

6. Assir MZK, Kamran U, Ahmad HI, Bashir S, Mansoor H, Anees SB, Akram J. Effectiveness of platelet transfusion in dengue fever: A randomized controlled trial. Transfusion Medicine and Hemotherapy 2013; 40:362-8. http://dx.doi.org/10.1159/000354837 PMid: 24273491 PMCid: PMC3822277

7. Jain A, Chaturvedi UC. Dengue in infants: an overview. FEMS Immunology and Medical Microbiology 2010; 59(2):119-30. http://dx.doi.org/10.1111/j.1574695X.2010.0067 0.x 